Anna Jakimowicz

Uniwersytet Marii Curie-Skłodowskiej w Lublinie

ORCID ID: 0000-0002-2638-7069
OBLICZA WOJNY

TOM 5 - MIASTO I WOJNA

ŁÓDŹ2021 •ISBN 978-83-8220-699-9 • s. 171-188

https://doi.org/10.18778/8220-699-9.10

\title{
W CIENIU WOJNY... KULTURA I CZAS WOLNY WOJSKOWYCH I LUDNOŚCI CYWILNEJ W LUBLINIE W OKRESIE OKUPACJI AUSTRO-WĘGIERSKIEJ (1915-1918)
}

\begin{abstract}
Streszczenie. Jesienią 1915 r. Lublin stał się stolicą Generalnego Gubernatorstwa Wojskowego, co spowodowało napływ wojskowych i ludności cywilnej z C.K. Monarchii oraz Galicji. Czas wolny od pracy wypełniano wyjściami do teatrów, kin, jak również restauracji i cukierni, co w efekcie wpłynęło do rozkwit sfery kulturalnej, a także branży gastronomicznej, hotelarskiej i usługowej. Lokalni przedsiębiorcy, by zyskać przychylność władz okupacyjnych, starali się sprostać ich potrzebom i oczekiwaniom, co nie było łatwe wobec rekwizycji towarów, drożyzny i spekulacji czy utrudnionej komunikacji. Mimo to przez cały okres trwania okupacji pojawiały się nowe formy i miejsca rozrywki, których celem było zabawianie oraz chwilowe oderwanie od codziennych trosk. Korzystali z nich zarówno oficerowie, jak i cywile, powstały wówczas także dwie placówki przeznaczone dla wojskowych.
\end{abstract}

Słowa kluczowe: Lublin, kultura, rozrywka, czas wolny, Wielka Wojna, okupacja austro-węgierska

Jednym $z$ interesujących elementów życia codziennego, ukazującym dopiero od niedawna badane aspekty przeszłości, był czas wolny ${ }^{1}$. W analizach dotyczących historii ziem Królestwa Polskiego problematyka ta jest najczęściej

${ }^{1}$ Próby zdefiniowania „czasu wolnego” podejmowane są przez badaczy wielu dyscyplin naukowych, co wskazuje na złożoność i ambiwalentność tego zagadnienia, gdyż to, co dla jednych jest rozrywką i odpoczynkiem, dla innych może być pracą. Dlatego też sformułowanie to najczęściej używane jest jako antagonizm pracy - D. Mroczkowska, Wprowadzenie. Czas wolny. Refleksje, dylematy, perspektywy, [w:] Czas wolny. Refleksje, dylematy, perspektywy, red. D. MroCZKOwsKA, Warszawa 2011, s. 7-10; J. MoKras-GrabowsKa, Czas wolny w dobie postmodernizmu, „Folia Turistica" 2015 , nr 34, s. 12-15. 
poruszana jako komponent sfery kulturalnej i obyczajowej, konsumpcyjnej, zdrowotnej oraz sportowej ${ }^{2}$. Powszechną formą rozrywki³ zamożnej ludności w miastach i miasteczkach było uczęszczanie na przedstawienia teatralne, koncerty, występy artystyczne, pokazy kinematograficzne, wystawy oraz odczyty, a w zaciszu domowym - granie w gry karciane, warcaby, szachy bądź na instrumentach, jak również czytanie literatury. Ponadto istotne było podtrzymywanie relacji międzyludzkich poprzez wizyty w domach, uczestniczenie w balach, rautach, przejęciach publicznych i prywatnych, podczas których organizowano różnorodne salonowe formy rozrywki $i^{4}$. Osoby, które lubiły spędzać czas aktywnie, korzystały z zabaw i sportów na świeżym powietrzu. Niemal codzienną aktywnością było „bywanie” w pierwszorzędnych cukierniach i kawiarniach pełniących funkcje „salonów publicznych”, w sezonie letnim zaś spacerowano po parkach i ogrodach miejskich. Najlepsze restauracje, znane z wykwintnych dań i bogatej oferty trunków, stanowiły miłą odmianę od domowych posiłków, natomiast wieczorami stawały się azylem dla mężczyzn ${ }^{5}$. Niejednokrotnie dochodziło do niekulturalnych zachowań w lokalach i na ulicach, sprowadzających się najczęściej do awantur i bójek. W takiej formie

2 A. Chwalba, Obyczaje w Polsce. Od średniowiecza do czasów wspótczesnych, Warszawa 2004; M. JASKÓLSKI, Piwo, flaki garnuszkowe, petersburskie bliny i kawior astrachański, czyli $z$ dziejów gastronomii tódzkiej do 1918 roku, Łódź 2012; M. i L. TrZECIAKOwSCY, Styl życia miejskiego w XIX-wiecznym Poznaniu, [w:] Miasto i kultura polska doby przemystowej. Cztowiek, red. H. IMBS, Wrocław-Warszawa-Kraków 1993, s. 75-103; A. CzAJKA, Moda kobieca na rower, [w:] Życie prywatne Polaków w XIX wieku, t. 6: Moda i styl życia, red. J. KiTA, M. KorYBUT-MarCiniaK, Łódź-Olsztyn 2017, s. 219-220; D. WIĘCEAWEK, Jak zabić czas i zaimponować towarzystwu? Gry i zabawy w świetle poradników XIX i XX wieku, [w:] Sport i czas wolny w perspektywie interdyscyplinarnej, red. D. NowALSKA-KAPUŚCIK, G. LiBOR, 2018, e-book, s. 47-53; A. ŻARnOwSKA, Codzienność i kultura: w kregu rodziny i wśród innych, [w:] Kobieta i kultura życia codziennego, t. 5: Wiek XIX i XX, red. A. ŻARnOwSKA, A. SzWARC, Warszawa 1997, s. 17-28; D. RzePniEwsKA, Ziemianki w mieście. Królestwo Polskie w końcu XIX wieku, [w:] Kobieta i kultura..., s. 52.

${ }^{3}$ Formy spędzania czasu wolnego były mocno zróżnicowane z racji podziału klasowego, warunków społecznych i materialnych ludności zamieszkującej dany obszar, vide: E. DEPA, Kultura w socjologii - wybrane zagadnienia, „Rzeszowskie Studia Socjologiczne” 2017, nr 9, s. 54; A. LisAK, Życie towarzyskie w XIX wieku, Warszawa 2013-2017, s. 91, 96-97.

${ }^{4}$ D. WIĘCEAWEK, op. cit., s. 45-53.

${ }^{5}$ J. Pawlikowski, Pijana twierdza. Alkohol $w$ życiu żotnierzy toruńskiego garnizonu $w$ latach 1815-1920, [w:] Alkohol w wojsku i na wojnie. $Z$ dziejów wojskowości polskiej i powszechnej, t. 7, red. A. NiewIŃSKI, Oświęcim 2018, s. 185-186 i 196. 
objawiała się kultura niższa, o której więcej się mówiło, niż pisało na kartach pamiętników czy lokalnej prasy.

W okresie pierwszej wojny światowej życie kulturalne i rozrywkowe w ośrodkach miejskich na terenie okupacji austro-węgierskiej wbrew pozorom nie zostało zahamowane, a nawet można uznać, że stanowiło najszybciej rozwijającą się wówczas sferę, która przynosiła korzyści materialne. Rozkwit dotyczył nie tylko teatrów i kin, ale również lokali gastronomicznych, hoteli oraz usług handlowych, które starały się dostosować do realiów wojennych mimo napotykanych trudności. Ponadto powstają nowe miejsca rozrywki i spędzania czasu wolnego przeznaczone wyłączenie dla wojskowych. Przeobrażenia te odzwierciedlał Lublin, który w latach 1915-1918 pełnił funkcję stolicy Generalnego Gubernatorstwa Wojskowego (dalej: GGW). Nastąpił napływ wojskowych i cywilów z C.K. Monarchii oraz Galicji, wśród których dominowali oficerowie, a następnie urzędnicy. Wielu z nich po rozpoczęciu pracy w administracji Zarządu Wojskowego oraz znalezieniu odpowiedniego lokum sprowadzało do miasta swoje rodziny bądź przyjaciółki. Przedstawiciele austriackiej elity, przyzwyczajeni do wystawnego i luksusowego stylu życia, bogatej i urozmaiconej oferty rozrywek w wielkomiejskich ośrodkach, dyktowania trendów w sferze kulturalnej oraz modzie, mieli wysokie oczekiwania wobec Lublina i jego mieszkańców, którzy za panowania Rosjan starali się naśladować styl życia warszawskiego ${ }^{6}$. Rychłe zmiany, które nastąpiły po przejęciu władzy przez Austriaków, spowodowały wzmocnienie podziału klasowego między grupą osób majętnych i uprzywilejowanych przybywającą do miasta a lublinianami, którzy zmagali się z drożyzną i deficytem żywności, artykułów pierwszej potrzeby, a także brakiem pracy

${ }^{6}$ D. SZYMCZAK, Nad modrym Dunajem. Refleksje o życiu codziennym polskich polityków w Wiedniu w okresie konstytucyjnym 1861-1914, „Galicja. Studia i Materiały” 2018, nr 4, s. 24-43. Po powstaniu styczniowym wraz z rozkwitem kapitalizmu nastąpił rozwój miasta pod względem przemysłowym, gospodarczym i handlowym, podnosząc jego znaczenie poza skalę regionalną. Jednakże w sprawach oświaty i kultury panowała stagnacja, pozostawiając Lublin w tyle za innymi szybko rozwijającymi się ośrodkami miejskimi na terenie zaboru rosyjskiego oraz Galicji, $c f:$ : W. ŚLADKOWSKI, W epoce zaborów, [w:] Lublin. Dzieje miasta, t. 2: XIX i XX wiek, red. T. RADZIK, W. ŚLADKOWSKI, G. WóJCIKOWSKI, W. WÓJCIKOWsKI, Lublin 2000, s. 171-172.

7 W 1914 r. Lublin zamieszkiwało ok. 80 tys. osób, a w połowie 1918 r. prawie 95 tys., $c f$ : A. KIEREK, Rozwój Lublina w latach 1864-1914, [w:] Dzieje Lublina. Próba syntezy, t. 1, red. J. DobRZAŃSKI J. KŁOCZOwSKi, J. MAZURKIEWICZ, Lublin 1965, s. 267; S. KRZYKAEA, Lublin w okresie walk rewolucyjnych 1918-1920, [w:] Dzieje Lublina, t. 2, red. S. KrZYKaŁA, Lublin 1975, s. 8. 


\section{Lublin - stolica Generalnego Gubernatorstwa Wojskowego (1915-1918)}

Latem 1915 r. w wyniku przesuwania się frontu na wschód wojska rosyjskie zostały zmuszone do ewakuacji z obszaru Królestwa Polskiego. W dniu 1 października 1915 r. Lublin stał się oficjalnie siedzibą Generalnego Gubernatorstwa Wojskowego, którą przeniesiono z Kielc ${ }^{8}$. Spowodowało to napływ ludności austriackiej i niemieckiej, która zaadaptowała na własny użytek gmachy byłych instytucji i organizacji rosyjskich, jak również całe zaplecze militarne, w tym koszary tzw. świętokrzyskie9. Równolegle stolica Lubelszczyzny stała się również znaczącym ośrodkiem niepodległościowym. Już w pierwszym roku wojny w Lublinie utworzono Polską Organizację Wojskową, a w kolejnych latach uruchomiono oddziały placówek militarnych zajmujących się akcją werbunkową oraz ewidencją ochotników do Legionów Polskich (dalej: LP) ${ }^{10}$. W efekcie miasto stało się dla wojskowych i urzędników miejscem pobytu stałego, ale też etapem w ich wojennej wędrówce. Ponadto pełniło także funkcję punktu tranzytowego dla żołnierzy, którzy jechali z frontu na urlop do domu bądź z niego wracali ${ }^{11}$.

8 Obszar GGW dzielił się na 24 komendy powiatowe wraz z enklawą Jasnej Góry. W czerwcu 1916 r. włączono trzy nowe powiaty. Jan Lewandowski pisał, że już jesienią 1915 r. na tym terenie przebywało wojsko liczące do 150 tys. żołnierzy, vide: J. LEWANDowski, Królestwo Polskie pod okupacja austriacka 1914-1918, Lublin 1980, s. 39 i 43. W latach 1915-1918 stanowisko generat-gubernatora zajmowali kolejno: Erich von Diller, Karl Kuk, Anton Lipoščak, Stanisław hr. Szeptycki, cf:: IDEM, Lubelscy c.k. generatowie-gubernatorzy (1915-1918), „Annales Universitatis Mariae Curie-Skłodowska” 2013, sectio F, vol. 68, z. 1-2, s. 7-23.

9 Placówki administracyjne, banki, obiekty militarne były usytuowane przy głównej arterii miasta, czyli ul. Krakowskie Przedmieście, a siedziba generał-gubernatora mieściła się w Pałacu Gubernialnym, w ścisłym centrum, przy dawnym placu Musztry (obecnie plac Litewski).

10 Jesienią 1915 r. równocześnie werbunek prowadziły C.K. Komeda Legionów oraz biuro werbunkowe I Brygady. W akcję zaangażowani byli także członkowie Lubelskiego Wydziału Narodowego oraz działacze polityczni, vide: J. Konefat, Do Ciebie, Polsko... Legiony Polskie w Lubelskiem 19141918, Lublin 2008, s. 107 i 125; Centralne Archiwum Wojskowe (dalej: CAW), Legiony Polskie i Polski Korpus Posiłkowy (dalej: LP i PKP), sygn. 120.1.3, Akta sztabowe ck Komendy LP, Organizacja werbunku na okupacji austriackiej, 1916, k. 169-170; S. LELEK, P.O.W. w walce o niepodlegtość, [w:] Pod sztandarem P.O.W. Szkice i wspomnienia zebrane dla uczczenia uroczystości poświęcenia sztandaru, odstonięcia tablicy pamiątkowej s.p. ptk. Mieczystawa Więckowskiego i potączenia okregu siedleckiego Związu Peowiaków z okręiem lubelskim: Lublin w marcu 1935 roku, red. F. ARNSZTAJNOwA, Lublin 1935, s. 20-24; Biuro oficera werbunkowego Legionów Polskich w Lublinie, „Gazeta Ludowa” (dalej: „Gaz. Lud.”) 1916, nr 12 z 9 stycznia, s. 12.

11 J. KonefaE, op. cit., s. 207. 
$\mathrm{Z}$ racji nieregularnych i opóźnionych godzin przyjazdów i odjazdów pociągów, zamiast czekać na zatłoczonym dworcu, niektórzy udawali się do centrum miasta. Przykładowo kapelan Legionów Polskich ks. Kazimierz Nowina-Konopka o kilkugodzinnym pobycie w mieście pisał: „Przez pół dnia nie było co robić, siedziało się w cukierni, to w restauracji, byle doczekać do wieczora i do pociągu"12. Niektórzy szli na skromne zakupy, odwiedzali znajomych bądź udawali się na krótkie zwiedzanie miasta ${ }^{13}$.

Na przełomie 1915 i 1916 r. władza austriacka, by zyskać przychylność społeczeństwa, zaczęła „liberalizować” swą postawę wobec wieloaspektowego życia publicznego. Wyrażono zgodę na zakładanie instytucji społecznych, oświatowych i kulturalnych, zezwolono na organizowanie wydarzeń o charakterze patriotycznym, pod warunkiem zachowania porządkư ${ }^{14}$. Ta sytuacja stworzyła okupantom nie lada okazję do czerpania zysków finansowych na rzecz C.K. Monarchii, gdyż właściciele kin i teatrów musieli podjąć współpracę z krakowskimi oraz wiedeńskimi przedstawicielami środowiska artystycznego, jak również nałożono na wszelkie wydarzenia komercyjne podatek od widowisk i zabaw publicznych. Normą było też wykorzystywanie nośników kultury w celach propagandowych ${ }^{15}$.

Dyrektor Teatru Wielkiego w Lublinie Henryk Halicki, by zdobyć aprobatę władzy okupacyjnej, wystawiał dzieła wywodzące się głównie z twórczości niemieckiej i austriackiej. Wśród utworów dramatycznych królowały Honor Hermanna Sudermanna oraz Samotni Gerharta Hauptmanna, wśród oper i operetek zaś największą popularnością cieszyły się: Baron Cygański oraz Zemsta Nietoperza Johanna Straussa syna, Baron Kimmel Waltera Kolo, Księżniczka czardasza Imrego Kálmána. Przeszkodą dla austriackich oficerów i urzędników w czerpaniu przyjemności z oglądania przedstawień teatralnych była nieznajomość języka polskiego, co powodowało, że najczęściej udawali się na operetki, w których dominowały taniec i śpiew. Natomiast wśród Polaków największe zainteresowanie wzbudzały dzieła o tematyce patriotycznej i historycznej, które w okresie panowania Rosjan

\footnotetext{
12 K. Nowina-Konopka SJ, Wspomnienia wojenne 1915-1920, Kraków 2011, s. 35.

13 S. ŻMigrodZKI, Przed i po 6 sierpnia. Wspomnienia oficera taczności I. Brygady, Warszawa 1935, s. 170 .

14 Analogiczna sytuacja panowała pod okupacją niemiecką, vide: A. STAWISZYŃSKA, Eódź w latach I wojny światowej, Oświęcim 2016, s. 177.

15 Ibidem, s. 139-140.
} 
były zakazane ${ }^{16}$. Repertuar mniejszych teatrów obejmował przede wszystkim utwory lekkie takie jak: operetki, komedie, farsy, krotochwile czy wodewile. Uczęszczano także na występy objazdowych teatrów legionowych ${ }^{17}$, z niecierpliwością oczekiwano też wiedeńskiego teatru frontowego, który pojawił się w Lublinie w listopadzie $1917 \mathrm{r}^{18}$

Rozkwit przeżywały również lubelskie bioskopy, które przed wojną nie cieszyły się uznaniem wśród lublinian. Już jesienią 1915 r., aby zyskać zainteresowanie obecnych w mieście Austriaków i Niemców, zaczęto sprowadzać z C.K. Monarchii krótkometrażowe filmy najnowszej produkcji z polsko-niemieckimi napisami. W „Ziemi Lubelskiej” pisano:

Kubicki [właściciel bioskopu Louvre - A.J.] powrócił z Wiednia i Budapesztu, skąd sprowadził z napisami polsko-niemieckimi, nie szczędząc kłopotów, trudności i kosztów szereg sensacyjnych obrazów. (...) jest obecnie demonstrowany wielce zajmujący dramat pt. Pani Gertruda do czego temat zaczerpnięto z życia mieszkańców Wiednia ${ }^{19}$.

Z kolei w kinie „Polonia”, które często było odwiedzane przez żołnierzy, wyświetlano kroniki wojenne produkowane w Wiedniu, jak również filmy o charakterze propagandowym, np.: Zdobycie Przemyśla, Bitwa pod Marna, uroczystości pogrzebowe cesarza Franciszka Józefa, a także nowoczesne technologie militarne ${ }^{20}$. Pokazom tym starano się nadać patetyczną oprawę, stąd często towarzyszyła im muzyka wojskowa ${ }^{21}$. Z kolei Wacław Kazanowski oraz Józef

16 Pochodziły one m.in. z twórczości Stanisława Moniuszki i Stanisława Wyspiańskiego, vide: Ze sceny i estrady, „Ziemia Lubelska” (dalej: „ZL”) 1917, nr 18 z 11 stycznia, s. 4; Ze sceny i estrady, „ZL” 1917, nr 278 z 5 czerwca, s. 3; Teatr Wielki, „ZL” 1917, nr 412 z 18 sierpnia, s. 4; Teatr Wielki, „ZL” 1918, nr 6 z 4 stycznia, s. 3; Teatr Wielki, „ZL” 1916, nr 18 z 16 stycznia, s. 6; Teatr Wielki, „Głos Lubelski” (dalej: „GL”) 1915, nr 297 z 27 października, s. 2; Teatr Wielki, „GL” 1916, nr 124 z 7 maja, s. 2.

17 W Lublinie zespół przebywał przez 3 miesiące w 1916 r., cf: S. PIEKARSKI, Polskie teatry żotnierskie 1915-1918, Warszawa 1999, s. 25-30.

18 Wiedenski niemiecki teatr frontowy w Lublinie, „ZL” 1917, nr 591 z 24 listopada, s. 2.

19 Z kinematografu „Louvre”, „GL” 1916, nr 44 z 15 lutego, s. 2; Z „Louvru”, „ZL” 1916, nr 14 z 16 stycznia, s. 2. Również kierownicy kina „Polonia” nawiązali owocną współpracę z wiedeńskimi firmami, które zajmowały się przygotowywaniem napisów, vide: Bioskop „Polonia”, „ZL” 1916, nr 209 z 1 maja, s. 1 .

${ }^{20}$ Obchód pogrzebowy cesarza Franciszka Józefa w kinie, „GL” 1916, nr 340 z 9 grudnia, s. 3; W kino-teatrze „Polonia”, „ZL” 1916, nr 335 z 11 lipca, s. 2.

21 Z bioskopu „Louvre”, „GL” 1916, nr 222 z 13 sierpnia, s. 3. 
Kozłowski, właściciele największego w mieście kino-teatru „Oaza”, nowości filmowe sprowadzali z warszawskiej wytwórni „Sfinks”22. Głośne obrazy z tego czasu ukazujące rządy władzy carskiej to Ochrana warszawska i jej tajemnice, która krążyła pomiędzy bioskopami lubelskimi ${ }^{23}$, a także Carat i jego stugi, nagrywany na ulicach Warszawy ${ }^{24}$. Jednakże największym zainteresowaniem cieszyły się filmy ze wschodzącą gwiazdą kina niemego Polą Negri, np. Studenci, Bestja czy farsa Chcemy męża $a^{25}$.

Wpływ obecności obywateli C.K. Monarchii widoczny był również w programach koncertowych, w których grano muzykę światowej sławy twórców: Richarda Wagnera, Carla Marii von Webera, Henriego Vieuxtemps'a, Giacoma Pucciniego, Ruggera Leoncavalla oraz Bedřicha Smetany ${ }^{26}$. Z kolei od połowy lipca 1916 r. na deskach Teatru Wielkiego zaczęła występować orkiestra c.k. $58 \mathrm{pp}^{27}$. Wskazane było uczestnictwo w wieczornych wydarzeniach o charakterze dobroczynnym, organizowanych pod protektoratem generał-gubernatora ${ }^{28}$. O ile dla jednych mógł być to przykry obowiązek, o tyle dla innych oznaczało to możliwość spędzenia przyjemnego wieczoru, a także poszerzenia grona znajomych. Jan Hupka, który przyjechał do miasta w sprawach politycznych Naczelnego Komitetu Narodowego, uczestniczył w koncercie zorganizowanym przez żonę generał-gubernatora Ericha von Dillera. Tak pisał o tym wydarzeniu: „Sala koncertowa nad teatrem była przepełniona. Zastałem tu mnóstwo znajomych, bo byli ci wszyscy lublinianie, z którymi się zetknąłem i wszyscy urzędnicy gubernialni i oficerowie Polacy"29.

22 „Oaza”, „ZL” 1915, nr 323 z 4 października, s. 2.

23 M. GUZEK, Kino polskie wczoraj i dziś. Co wspólnego z wojną ma kinematograf. Kultura filmowa na ziemiach polskich w latach 1914-1918, Bydgoszcz 2014, s. 412.

24 Ibidem, s. 419.

25 Kino „Oaza”, „ZL” 1917, nr 213 z 28 kwietnia, s. 4; Ogłoszenie, „ZL” 1917, nr 291 z 12 czerwca, s. 1; Ogłoszenie, „ZL” 273, nr 273 z 2 czerwca, s. 1.

26 Koncert na cele Centralnego Komitetu Ratunkowego w Lublinie, „Myśl Żydowska” 1916, nr 33 z 14 listopada, s. 7; Koncert, „ZL” 1917, nr 58 z 1 lutego, s. 3; Koncert symfoniczny, „ZL” 1918, nr 2 z 2 stycznia, s. 2.

27 S. KRUK, Życie teatralne w Lublinie (1782-1918), Lublin 1982, s. 200.

28 Przykładem był koncert zorganizowany we wrześniu 1916 r. pod protektoratem Amalii Kuk, na który sprowadzono prof. Schwarzesteina z Krakowa oraz członka Wiedeńskiej Akademii Muzycznej i Wiedeńskiej Opery Ludowej, vide: Koncert na rzecz Gtównego Komitetu Ratunkowego, "ZL” 1916, nr 572 z 18 listopada, s. 4; Koncert na cele Centralnego Komitetu Ratunkowego w Lublinie, „Myśl Żydowska” 1916, nr 22 z 14 listopada, s. 7.

29 J. Hupka, Z czasów wielkiej wojny. Pamiętnik nie kombatanta, wyd. 2, Lwów 1937, s. 142-144. 
Skutkiem przedłużającej się wojny była też potrzeba tworzenia nowych i prostych form rozrywki, mających na celu „bawić i cieszyć”. Tym sposobem na scenach niewielkich teatrów, a nawet w salach lokali gastronomicznych zaczęly dominować występy kabaretowe ${ }^{30}$, popisy humorystyczne przyjezdnych komików, akrobatów, magików, a także wieczory spirytualistyczne i hipnozy ${ }^{31}$. Zainteresowaniem cieszyły się również pokazy tańców staropolskich (mazura, polki, poloneza) ${ }^{32}$, walca wiedeńskiego oraz nowoczesnego ${ }^{33}$. Nadal jednak nie stroniono od kankana ${ }^{34}$. Wedle zwyczaju mężczyźni adorowali lubelskie artystki, które otrzymywały kwiaty oraz „prezenty w postaci pięknych tortów lub innych wyszukanych środków żywnościowych" ${ }^{35}$.

W okresie letnim główną atrakcją w mieście stawał się ogród Saski, w którym urządzano wszelkiego rodzaju uroczystości, loterie i zabawy ${ }^{36}$. Kilka razy w tygodniu w porze wieczornej przygrywała orkiestra ${ }^{37}$. Doniosłym wydarzeniem był festyn zorganizowany w połowie sierpnia 1918 r. z okazji urodzin cesarza Karola, podczas którego dostępne były darmowy bufet i cukiernia z przekąskami, odbyły się koncert czterech wojskowych kapel, przedstawienie teatralne, a wieczorem pokaz sztucznych ogni ${ }^{38}$.Z kolei zakład kąpielowy na Sławinku pod Lublinem zyskał nowe oblicze po otworzeniu eleganckiej restauracji w połowie 1917 r., do której sprowadzano kuchmistrza z krakowskiego zakładu „A. Hawełka”. Oferowano tam również noclegi w luksusowo umeblowanych pokojach, do tego krokieta,

30 Archiwum Państwowe w Lublinie (dalej: APL), Akta miasta Lublina 1915-1918 (dalej: AmL), sygn. 189, Podatek od widowisk, Sprawozdanie z wpływów podatku od widowisk I-VI 1918, s. 4-5. Występy zespołów kabaretowych najczęściej organizowano w restauracji „Belle Vue” przy ul. Krakowskie Przedmieście 36, vide: Ogłoszenie, „ZL” 1918, nr 380 z 11 sierpnia, s. 1.

31 Występ J. Zejdowskiego, Teatr „Miniature”, „ZL” 1917, nr 410 z 17 sierpnia, s. 4; Wieczory hipnozy, „GL” 1918, nr 12 z 12 stycznia, s. 3; Kronika, „GL” 1915, nr 24 z 24 stycznia, s. 3.

32 Teatr Wielki, „GL” 1916, nr 352 z 21 grudnia, s. 3.

33 Z „Wesotego Ula”, „ZL” 1916, nr 304, s. 2.

${ }^{34}$ Teatr Wielki, „GL” 1915, nr 227 z 17 sierpnia, s. 2.

35 L. Turnau, Wspomnienia $z$ pobytu w Lublinie, http://biblioteka.teatrnn.pl/dlibra/Content/10829/Wspomnienie_z_pobytu_w_Lublinie.pdf (dostęp: 20 X 2020).

36 Zabawa ogrodowa na chorych Legionistów, „ZL” 1916, nr 298 z 20 czerwca, s. 3; Dzisiejsza zabawa w ogrodzie Saskim, „GL” 1916, nr 124 z 7 maja, s. 2; Znaczek i zabawa ogrodowa, „ZL” 1918, nr 288 z 22 czerwca, s. 3.

37 Muzyka w ogrodzie miejskim, „ZL” 1917, nr 330 z 14 kwietnia, s. 4; Nowa orkiestra, „ZL” 1917, nr 290 z 12 czerwca, s. 4.

${ }^{38}$ Wielki festyn w Ogrodzie Saskim, „GL” 1918, nr 222 z 14 sierpnia, s. 3; Dzień urodzin cesarza Karola, „GL” 1918, nr 227 z 19 sierpnia, s. 2. 
strzelnicę oraz pływanie łódkami po dwóch stawach ${ }^{39}$. W niedziele i święta przyjeżdżał zespół muzyczny, a także organizowano pokazy ogni bengalskich i rakiet ${ }^{40}$. Latem następnego roku pojawiła się w mieście nowa forma rozrywki, a raczej dyscypliny sportowej - zawodowe zapasy mężczyzn. Walki rozgrywane w czterech stylach: francuskim, bokserskim, wolnoamerykańskim i szwajcarskim odbywały na terenie ogrodu przy kinie „Bajka”, który uruchomiono w czerwcu 1918 r. $^{41}$ W sierpniu zorganizowano Turniej o mistrzostwo miasta Lublina, w którym wzięli udział znani bokserzy z Warszawy, Krakowa i Poznania, jak również z zagranicy, m.in. z Finlandii, Rosji oraz terenów dzisiejszej Litwy, Łotwy i Ukrainy ${ }^{42}$.

Zaprezentowane formy i sposoby spędzania czasu wolnego przeznaczone były zarówno dla austriackich wojskowych i austriackiej ludności cywilnej, jak i dla elity lubelskiej, która starała się utrzymywać odpowiednie stosunki z władzą okupacyjną. Ponadto w omawianym okresie powstały dwa ośrodki, z których korzystali głównie żołnierze. Jednym z nich była Gospoda dla Legionistów, uruchomiona w grudniu 1915 r., która pełniła funkcję przytułku dla żołnierzy jadących na front lub z niego powracających. Na rzecz placówki oraz napływających do miasta legionistów wiele lokalnych towarzystw organizowało zbiórki żywności, odzieży, pieniędzy, a także różne inicjatywy kulturalno-rozrywkowe. Wyposażenie lokalu było skromne, gdyż większość mebli została ofiarowana, jednakże stało w nim pianino, na którym przygrywano podczas coniedzielnych wieczornic z pieśniami żołnierskim ${ }^{43}$. W gospodzie oficerowie i szeregowcy mogli zjeść, pogawędzić i pograć w karty, aczkolwiek obowiązywał zakaz wyszynku alkoholu ${ }^{44}$. Tutaj również odbywały się okazjonalne uroczystości, np.: wieczerze wigilijne, śniadania wielkanocne (tzw. święcone) oraz wizyty ważnych gości, m.in. komendanta LP gen. Stanisława Puchalskiego ${ }^{45}$. W bliskiej odległości członkinie Ligi kobiet urządziły Czytelnię dla Legionistów, która cieszyła się dużym zainteresowaniem ${ }^{46}$.

${ }^{39}$ L. Turnau, op. cit., s. 45.

40 Ogłoszenie, „ZL” 1917, nr 407 z 15 sierpnia, s. 1; Ogłoszenie, „GL” 1918, nr 107 z 21 kwietnia, s. 5.

41 Ogłoszenie, „GL” 1918, nr 230 z 22 sierpnia, s. 1.

42 Ogłoszenie, „GL” 1918, nr 221 z 13 sierpnia, s. 1; Z „Bajki”, „Dziennik Lubelski” 1918, nr 309 z 13 sierpnia, s. 4 .

43 Wieczornica w „Gospoda dla Legionistów”, „Gaz. Lud.” 1916, nr 11 z 12 stycznia, s. 1.

${ }_{44}$ J. KONEFAe, op. cit., s. 274-276 i 278.

${ }^{45}$ Ibidem, s. 277.

46 Wiadomości bieżące, „Gaz. Lud.” 1916, nr 21 z 21 maja, s. 12-13. 
Z kolei oficerowie armii austriackiej na posiłki udawali się do menaży gubernatorskiej, czyli Klubu Oficerskiego, na którą zaadaptowano pomieszczenia w gmachu byłego Banku Rosyjskiego. Kuchnią mensy zarządzał doskonały kucharz, pracujący przed wstąpieniem do armii u boku Sachera, znanego w Krakowie i Wiedniu cukiernika ${ }^{47}$. Do dyspozycji były trzy sale klubowe, spośród których jedną przeznaczono na dobrze wyposażoną w prasę i czasopisma czytelnię, znalazły się tam także fortepian, bilard i stoliki do gry w karty. Często grano w kręgle przy dźwiękach muzyki wojskowej ${ }^{48}$. W okresie sprawowania władzy przez Ericha Dillera w klubie systematycznie odbywały się partyjki brydża, zawsze po obiedzie i kolacji. Stawki był wysokie, osiągające nawet ok. 10 procent miesięcznej pensji kapitana. Jednakże po usunięciu Dillera ze stanowiska grywano coraz rzadziej ${ }^{49}$.

Niemal codziennym zwyczajem zarówno kobiet, jak i mężczyzn były wyjścia na kawę i ciastka do najlepszych cukierni i kawiarni w mieście. Austriacy najczęściej odwiedzali cukiernię Władysława Rutkowskiego, mieszczącą się w gmachu Kasy Przemysłowców, naprzeciw menaży ${ }^{50}$. Natomiast Legioniści bywali u „Semadeniego", vis-à-vis kina Polonia. W obrębie ul. Krakowskie Przedmieście uruchomiono wówczas szereg eleganckich restauracji. Przykładem była „Europejska" Aleksandra Jurkiewicza, otworzona w maju 1916 r., w której oferowano „wykwintne śniadania i kolacje od 60 kop. oraz doborowe trunki”ફ1. Dzięki napływowi zamożnego towarzystwa branża gastronomiczna była jednym z najlepiej rozwijających się działów usługowych, mimo wielu trudności, takich jak rekwizycje czy ograniczenie spożywania chleba oraz cukru. Jesienią 1916 r. władze okupacyjne wprowadziły rozporządzenie zakazujące wyrobu i sprzedaży białego pieczywa, a w styczniu kolejnego roku zabroniono podawania klientom więcej niż 2 kawałki cukru na 1 szklankę/filiżankę, jak również stawiania na stole cukierniczek ${ }^{52}$.Zdarzało się jednak, że spod zakazu wyłączano pierwszo-

${ }^{47}$ L. TURnAU, op. cit., s. 41; D. SZYMCZAK, op. cit., s. 34.

${ }^{48}$ L. Turnau, op. cit., s. 45 i 61.

49 Ibidem, s. 41-42.

50 Ibidem, s. 45.

51 Ogłoszenie, „ZL” 1916, nr 230 z 13 maja, s. 1.

${ }^{52}$ Za niezastosowanie się do tego nakazu groziła kara grzywny do 2 tys. koron bądź aresztu do 6 miesięcy, APL, C.K. Komenda Powiatowa w Lublinie 1915-1918 (dalej: KPL), sygn. 166, Sprawy aprowizacyjne m. Lublina, Obwieszczenie z 25 I 1917, k. 16; M. MAZur, Everyday Life in Lublin in 1918, „Res Historica” 2019, t. 48, s. 141. 
rzędne cukiernie i restauracje, które dostawały przykładowo pozwolenie na wyrób i sprzedaż lodów ${ }^{53}$. Nową formą uatrakcyjnienia wieczorów w lokalach było zatrudnienie dwu- lub trzyosobowych zespołów muzycznych. Nowość tę wprowadzano praktycznie we wszystkich najlepszych zakładach, a nawet w kilku II i III kategorii ${ }^{54}$. W restauracji „Reneissance” Józefa Zwolińskiego przygrywało męskie trio pod kierunkiem Wilhelma Viertla, w późniejszym zaś okresie orkiestra kobieca ${ }^{55}$. Natomiast w „Barze Wiedeńskim” Jana Mazurkiewicza wieczory umilało trio artystyczne pod batutą Stanisława Stembrowicza ${ }^{56}$. Wiosną $1917 \mathrm{r}$. Austriacy, żeby poprawić sytuację kasy miejskiej, nałożyli podatek muzyczny na lokale, co spowodowało, że wielu właścicieli zakładów zrezygnowało z dodatkowej rozrywki ${ }^{57}$.

W omawianym okresie istotne znaczenie miało podtrzymywanie kontaktów towarzyskich oraz zawieranie nowych znajomości. Dlatego uczestniczono w wydarzeniach organizowanych przez lokalne instytucje i zrzeszenia. Jedną z takich inicjatyw była tzw. Czarna Kawa urządzana przez lubelskie działaczki i członkinie Ligi Kobiet w restauracji pensjonatu „Janina” bądź w Resursie Kupieckiej. Uczestników tego typu spotkań obowiązywały eleganckie stroje, każdy miał też przydzielone miejsce przy stoliku. Programy tych wydarzeń wypełnione były występami artystycznymi, loteriami oraz grami, takimi jak np. zabawa w "pocztę francuską" 58 . Gdy spodziewano się przyjazdu do miasta ważnych osobistości, lubelscy działacze czynili starania o odpowiednią oprawę takich wizyt. Przykładem był przyjazd komendanta LP gen. Karola Durskiego, na którego cześć wydano uroczysty bankiet w „Janinie”, uświetniony licznymi przemowami i toastami ${ }^{59}$.Z kolei w menaży gubernatorskiej general-gubernator Diller często

53 Obwieszczenie z dn. 4 VI 1917, „ZL” 1917, nr 292 z 11 czerwca, k. 4.

54 Ogłoszenie, „Kalendarz Lubelski na rok zwyczajny 1917”, s. 145; APL, KPL, sygn. 69, Obchody i uroczystości, Do C.K. Komendy Powiatowej od T. Langego, 21 X 1918, k. 39.

55 Ogłoszenie, „ZL” 1915, nr 387 z 9 listopada, s. 2; Ogłoszenie, „ZL” 1918, nr 200 z 3 maja, s. 4; Dział ogłoszeń, „Kalendarz Lubelski na rok zwyczajny 1918”, s. 145.

56 Ogłoszenie, „ZL” 1917, nr 320 z 28 czerwca, s. 1.

57 APL, AmL, sygn. 87, Akta dotyczące przedłużenia godzin policyjnych i wprowadzenia muzyki w lokalach publicznych za okres I-XI 1917 r. oraz Pismo dotyczące godzin policyjnych z 8 III 1917 r., k. 20.

58 Czarna kawa, „ZL” 1916, nr 42 z 29 stycznia, s. 3; Czarna Kawa, „ZL” 1916, nr 510 z 15 października, s. 2.

59 Ekscel. Durski na ziemiach Królestwa, „Goniec Polowy Legionów” 1916, nr 12 z 15 stycznia, s. 4-5; J. HUPKA, op. cit., s. 138-141; A. KRASICKI, op. cit., s. 384-385. 
urządzał wystawne obiady ${ }^{60}$. Należy wspomnieć, że w okresie wojny unikano organizowania zabaw tanecznych, uważając taniec za czyn nieobywatelski ${ }^{61}$.

Późnymi wieczorami restauracje i kawiarnie cieszyły się popularnością zwłaszcza wśród mężczyzn, którzy po spektaklach bądź koncertach udawali się pograć w karty, bilard czy kręgle, nie stroniąc od alkoholu, cygar, a także towarzystwa kobiet lekkich obyczajów. W ramach urozmaicenia wieczoru zdarzały się przypadki celowego tłuczenia szkła i zastawy restauracyjnej ${ }^{62}$. Utrudnieniem zarówno dla klientów, jak i dla właścicieli zakładów były obowiązujące godziny policyjne. Właścicielka kawiarni „Ziemiańska”, mieszczącej się w Hotelu Europejskim, zwracała się do władz okupacyjnych o przedłużenie godzin policyjnych do $1.00 \mathrm{w}$ nocy, gdyż austriaccy oficerowie narzekali na zbyt wczesne zamykanie lokalu ${ }^{63}$. Z racji czynnych do godziny 22.00 teatrów i kin pierwszorzędne restauracje zamykano o godzinie 23.00, a te niższej kategorii godzinę wcześniej ${ }^{64}$. W kwietniu 1917 r. w odpowiedzi na szereg próśb od dyrekcji placówek kulturalnych zezwolono, aby spektakle i pokazy kończyły się o godzinie 23.00, zamiast półtorej godziny wcześniej ${ }^{65}$. Ta ścisła korelacja między ośrodkami kulturalnymi a gastronomicznymi wymusiła na początku czerwca przesunięcie pory zamykania restauracji do północy, a trzy tygodnie później aż do godziny $2.00^{66}$. Lucjan Turnau wspomina jeden z wieczorów spędzonych w towarzystwie młodego por. księcia Ratibora:

raz w czasie partii kręgli, ktoś zafundował parę flaszek szampana, a raczej niemieckiego musującego „Sekta”, który był stale do nabycia w menaży gubernatorskiej. Ratibor kazał ustawić obok siebie sześć wysokich wąskich kieliszków napełnionych winem i założywszy ręce w tył chwytał kieliszki ustami i wychylał je kolejno jednym haustem, w takt muzyki ${ }^{67}$.

60 August Krasicki, który uczestniczył w uroczystym obiedzie, zwrócił uwagę na liczne grono oficerów i urzędników (ok. 100 osób), vide: A. KRASICKI, op. cit., s. 384.

61 M. MAZUR, op. cit., s. 153.

62 L. Turnau, op. cit., s. 61.

63 APL, AmL, sygn. 87, Do C.K. Komendanta Obwodu od Zofii Bakowskiej, 18 XII 1916, k. 2.

${ }^{64} \mathrm{~W}$ praktyce osoby średniozamożne musiały wybrać pomiędzy pójściem do restauracji lub kawiarni a wyjściem do bioskopy bądź na koncert: APL, AmL, sygn. 87, Do Magistratu od C.K. Komendy Obwodowej w Lublinie, 20 II 1917, k. 8.

65 APL, AmL, sygn. 87, Do Prezydenta miasta Lublina od C.K. Komendy Obwodu, 30 IV 1917, k. 29-30.

66 APL, AmL, sygn. 87, Do Prezydenta miasta Lublina od C.K. Komendy Obwodu, 26 VI 1917, k. 38-39.

67 L. Turnau, op. cit., s. 61. 
Nierzadko spotkania z restauracji przenoszono do pokoi hotelowych, które pełniły funkcję punktów kwaterunkowych oficerów austriackich. Tym sposobem większość hoteli była zajęta, co stwarzało duży problem dla osób przyjeżdżających do miasta $w$ interesach ${ }^{68}$. Najczęściej przydział otrzymywano w hotelach: Wenecja, Polskim, Staropolskim, Viktoria, Wersal, Saskim i Angielskim $^{69}$. Magistrat oferował zakwaterowanie w prywatnych mieszkaniach poza obszarem śródmieścia, jednakże większość oficerów nie wyrażała zgody na przeniesienie ${ }^{70}$. Koszty noclegów, prania mundurów i bielizny ponosili właściciele obiektów, co tym bardziej budziło niezadowolenie przedstawicieli środowiska hotelarskiego. Zmiany nastąpiły dopiero w marcu 1918 r., kiedy to po interwencji generał-gubernatora Antona Lipoščaka u cesarza Karola rachunki za kwatery zajęte przez gażystów wojskowych, czyli oficerów i urzędników pod zarządem c.k. armii, zaczęto pokrywać z kasy Zarządu Wojskowego ${ }^{71}$.

Ulica Krakowskie Przedmieście, bogata w liczne hotele i restauracje, stała się wówczas miejscem, gdzie coraz częściej spotykano kobiety lekkich obyczajów. Powszechnie uważano, że w kilku hotelach (m.in. w Wenecji i Europejskim), ale przede wszystkim w wielu domach prywatnych prowadzono domy publiczne ${ }^{72}$. Austriacy w obawie o zdrowie żołnierzy rozpoczęli akcję wyszukiwania kobiet parających się nierządem, a następnie zmuszali je do poddawania się badaniom lekarskim. Wzrost liczby kobiet trudniących się prostytucją nie jest zaskoczeniem, zwłaszcza że większość z nich zeszła na złą drogę z powodu braku środków materialnych. Wobec rosnącej konkurencji latem 1916 r. lokalna prasa rozpisywała się o coraz śmielszych zachowaniach „nie-dam” na ulicach. Zdarzało się, że to prostytutki wchodziły do najlepszych lokali, uprzykrzając wieczory gościom, co powodowało oburzenie i niesmak wśród klientów, szczególnie płci pięknej. Aby zapobiec tego typu występkom, utworzono Policję Obyczajową, „która zabroniła wesołym damom chodzenia po Krakowskim Przedmieściu i ogrodzie Saskim, od

\footnotetext{
${ }^{68}$ APL, AmL, sygn. 136, Sprawy ogólne Wydziału Finansowego, Podanie Właścicieli Hoteli w Lublinie do Magistratu, 12 IV 1917, k. 155-157.

${ }^{69}$ APL, AmL, sygn. 136, Wykaz należności do wypłat właścicielom i dzierżawcom hoteli w Lublinie za lata 1915-1916, k. 157.

70 APL, AmL, sygn. 136, W. Bajkowski do C.K. Komendy Obwodowej w Lublinie, 5 III 1917, k. 153-154, 162.

${ }^{71}$ Wynagrodzenie za kwatery, „GL” 1918, nr 66 z 9 marca, s. 3.

${ }^{72}$ K. ZielińsKi, Żydzi Lubelszczyzny 1914-1918, Lublin 1999, s. 48-49; J. KoneFAe, op. cit., s. 208-209.
} 
godz. 6 rano do godz. $12 \mathrm{w}$ nocy, jak również uczęszczania do restauracji pierwszorzędnych" "73. Zmiany w podejściu do prostytucji obrazują dane ze sprawozdań medycznych, według których w 1914 r. sprawowano kontrolę nad 70 prostytutkami, w 1915 r. - nad 226, a w 1916 r. już nad 35074. Spoufalanie się z oficerami dotyczyło również kobiet z dobrych domów, czego dowodzi fragment diariusza ks. Józefa Rokosznego: „W Lublinie w wielu rodzinach panny i panie zaszły w stan poważny, a wiele choruje ciężko, dzięki zbliżeniu się z oficerami, opinia publiczna obecnie piętnuje te panie, które chodzą po mieście z oficerami”75.

Zdarzały się też nieprzyjemne sytuacje z użyciem broni palnej i białej. W aferę pojedynkową wplątał się pułkownik huzarów von der Lühe, który zamroczony alkoholem znieważył p. Mazurkiewicza, lubelskiego posiadacza ziemskiego. Następnego dnia urażony Mazurkiewicz zażądał satysfakcji. Pułkownik w pośpiechu opuścił miasto i wrócił do pułku, jednakże Mazurkiewicz za pośrednictwem sekundantów poinformował o całym zdarzeniu generał-gubernatora Dillera, który zezwolił na natychmiastowe odbycie pojedynku. W efekcie ucierpiały jedynie honor oraz płaszcz pułkownika, który został przestrzelony ${ }^{76}$. Napięte stosunki między legionistami a oficerami austriackimi były odczuwalne przez cały okres trwania okupacji. Najczęściej konflikty wynikały z nieoddawania sobie honorów. Zaczepki słowne, obelgi skutkowały skargami do przełożonych oraz licznymi raportami ${ }^{77}$. Oficer legionowy Roman Starzyński o nieprzyjemnym incydencie z 17 lipca $1916 \mathrm{r}$ z austriackim podoficerem pisał:

Po północy w dobrych humorach wracaliśmy do szpitala w kilku, kiedy zastąpił nam drogę pijany feldfebel austriacki i nie salutując myślał, że my zejdziemy mu z drogi. Kiedy na zwrócenie mu uwagi śmiał się coś odpowiadać, ppor. Gustaw Klarsfeld-Szczerski z 4 pp. LP dobył szabli i ciął go przez pysk, że krwią się zalał. Odprowadziliśmy go na odwach i zameldowaliśmy o nieodpowiednim zachowaniu się wobec oficerów legionowych ${ }^{78}$.

73 Zakaz, „GL” 1916, nr 221 z 17 maja, s. 2; Przeciwko prostytucji, „ZL” 1916, nr 396 z 14 sierpnia, s. 3.

${ }^{74}$ APL, AmL, sygn. 285, Akta dot. wydatków na utrzymane filii szpitala Św. Józefa w Lublinie, Do dr A. Gałuszki od zarządu szpitala Św. Józefa, 18 III 1916, k. 12; Chore kobiety, „ZL” 1916, nr 312 z 28 czerwca, s. 2.

75 J. Rokoszny, Diariusz Wielkiej Wojny 1915-1916, Kielce 1998, s. 227.

76 J. HUPKa, op. cit., s. 7.

77 J. Konefał, op. cit., s. 207-208.

${ }^{78}$ Na podstawie pracy J. Konefała wiadomo, że sprawa dotyczy poszkodowanego Rudolfa Rottera, a w gronie Legionistów znaleźli się: podporucznik 5 pp LP Stefan Rowecki, podchorąży Roman Stanepski oraz 2 mężczyzn, których nazwisk nie podano - ibidem, s. 211; R. STARZYŃSKI, op. cit., s. 253-254. 
Lubelskie życie kulturalne w okresie okupacji austro-węgierskiej mocno ewoluowało mimo trwającej wojny, cenzury i wydawanych rozporządzeń. Podział obszaru Królestwa Polskiego na dwie okupacje spowodował, że przestano wzorować się na Warszawie, a zaczęto śledzić, co dzieje się w Wiedniu i Krakowie. Napływ obywateli C.K. Monarchii i Galicji w znacznym stopniu przyczynił się do zmian, gdyż lublinianie byli świadomi istoty pozyskania - w tych niepewnych czasach - aprobaty i przychylności Austriaków. Dlatego też starano się spełniać ich wysokie wymagania w sferze kulturalnej, sprowadzając do miasta znanych artystów czy też obrazy z napisami. Najlepsze lokale gastronomiczne w mieście zapewniały gościom dania według kuchni wiedeńskiej i francuskiej, jak również ekskluzywne alkohole. Rosła liczba hoteli i noclegowni. Zmiany były dostrzegalne również w sklepach na śródmieściu, gdzie oferowano modne stroje według najnowszych fasonów i krojów wiedeńskich. Należy jednak zauważyć, że wszelkie rozrywki i instytucje kulturalne mieściły się w obrębie śródmieścia i w porównaniu z Warszawą, Krakowem czy Poznaniem było ich tam znacznie mniej, co dla młodych oficerów, szukających wrażeń i zapomnienia od codziennych trosk po kilkumiesięcznym pobycie mogło wydawać się nudne. Inaczej postrzegano sytuację, mając przy boku rodzinę, gdyż adaptowanie się w nowych miejscach wcale nie było łatwe. Te osoby częściej wyjeżdżały za miasto, żeby spędzić czas wolny z bliskimi np. na łonie natury.

\section{BIBLIOGRAFIA}

\section{Źródła archiwalne}

\section{Archiwum Państwowe w Lublinie}

C.K. Komenda Powiatowa w Lublinie 1915-1918, sygn. 69,675

Akta miasta Lublina 1915-1918, sygn. 87, 136, 285.

Centralne Archiwum Wojskowe, Wojskowe Biuro Historyczne

Legiony Polskie i Polski Korpus Posiłkowy, sygn. 120.1.3. 


\section{Źródła drukowane}

Hupka J., Z czasów wielkiej wojny. Pamiętnik nie kombatanta, wyd. 2, Lwów 1937.

Lelek S., P.O.W. w walce o niepodlegtość, [w:] Pod sztandarem P.O.W. Szkice i wspomnienia zebrane dla uczczenia uroczystości poświęcenia sztandaru, odstonięcia tablicy pamiątkowej s.p. ptk. Mieczystawa Więckowskiego i potączenia okregu siedleckiego Związku Peowiaków z okregiem lubelskim: Lublin w marcu 1935 roku, red. F. Arnsztajnowa, Lublin 1935 , s. 20-24.

Nowina-Konopka K. SJ, Wspomnienia wojenne 1915-1920, Kraków 2011.

Rokoszny J., Diariusz Wielkiej Wojny 1915-1916, Kielce 1998.

Żmigrodzki S., Przed i po 6 sierpnia. Wspomnienia oficera taczności I. Brygady, Warszawa 1935.

\section{Prasa i kalendarze}

„Dziennik Lubelski” 1918.

„Gazeta Ludowa” 1916.

„Głos Lubelski” 1915-1918.

„Goniec Polowy Legionów” 1916.

„Kalendarz Lubelski na rok zwyczajny 1917”.

„Kalendarz Lubelski na rok zwyczajny 1918”.

„Myśl Żydowska” 1916.

„Ziemia Lubelska” 1915-1918.

\section{Opracowania}

Chwalba A., Obyczaje w Polsce. Od średniowiecza do czasów wspótczesnych, Warszawa 2004.

Czajka A., Moda kobieca na rower, [w:] Życie prywatne Polaków w XIX wieku, t. 6: Moda i styl życia, red. J. Kita, M. Korybut-Marciniak, Łódź-Olsztyn 2017, s. 217-230.

Depa E., Kultura w socjologii - wybrane zagadnienia, „Rzeszowskie Studia Socjologiczne” 2017, t. 9, s. 49-59.

Guzek M., Kino polskie wczoraj i dziś. Co wspólnego z wojna ma kinematograf. Kultura filmowa na ziemiach polskich w latach 1914-1918, Bydgoszcz 2014.

Jaskólski M., Piwo, flaki garnuszkowe, petersburskie bliny i kawior astrachański, czyliz dziejów gastronomii tódzkiej do 1918 roku, Łódź 2012.

Kierek A., Rozwój Lublina w latach 1864-1914, [w:] Dzieje Lublina. Próba syntezy, t. 1, red. J. Dobrzański, J. Kłoczowski, J. Mazurkiewicz, Lublin 1965, s. 257-300. 
Konefał J., Do Ciebie, Polsko... Legiony Polskie w Lubelskiem 1914-1918, Lublin 2008.

Kruk S., Życie teatralne w Lublinie (1782-1918), Lublin 1982.

Krzykała S., Lublin w okresie walk rewolucyjnych 1918-1920, [w:] Dzieje Lublina, t. 2, red. S. Krzykała, Lublin 1975, s. 7-31.

Lewandowski J., Królestwo Polskie pod okupacją austriacką 1914-1918, Lublin 1980.

Lewandowski J., Lubelscy c.k. generatowie-gubernatorzy (1915-1918), „Annales Universitatis Mariae Curie-Skłodowska” 2013, sectio F, vol. 68, z. 1-2, s. 7-23.

Lisak A., Życie towarzyskie w XIX wieku, Warszawa 2013-2017.

Mazur M., Everyday Life in Lublin in 1918, „Res Historica” 2019, t. 48, s. 137-171.

Mokras-Grabowska J., Czas wolny w dobie postmodernizmu, „Folia Turistica” 2015, nr 34, s. 11-30.

Mroczkowska D., Wprowadzenie. Czas wolny. Refleksje, dylematy, perspektywy, [w:] Czas wolny. Refleksje, dylematy, perspektywy, red. D. Mroczkowska, Warszawa 2011, s. 7-10.

Pawlikowski J., Pijana twierdza. Alkohol w życiu żotnierzy toruńskiego garnizonu w latach 1815-1920, [w:] Alkohol w wojsku i na wojnie. Z dziejów wojskowości polskiej ipowszechnej, t. 7, red. A. Niewiński, Oświęcim 2018, s. 185-196.

Piekarski S., Polskie teatry żotnierskie 1915-1918, Warszawa 1999.

Rzepniewska D., Ziemianki w mieście. Królestwo Polskie w końcu XIX wieku, [w:] Kobieta i kultura życia codziennego, t. 5: Wiek XIX i XX, red. A. Żarnowska, A. Szwarc, Warszawa 1997, s. 31-56.

Stawiszyńska A., Łódź w latach I wojny światowej, Oświęcim 2016.

Szymczak D., Nad modrym Dunajem. Refleksje o życiu codziennym polskich polityków w Wiedniu w okresie konstytucyjnym 1861-1914, „Galicja. Studia i Materiały” 2018, nr 4, s. 24-43.

Śladkowski W., Wepoce zaborów, [w:] Lublin. Dzieje miasta, t. 2: XIX i XX wiek, red. T. Radzik, W. Śladkowski, G. Wójcikowski, W. Wójcikowski, Lublin 2000, s. 11-172.

Trzeciakowscy M. i L., Styl życia miejskiego w XIX-wiecznym Poznaniu, [w:] Miasto i kultura polska doby przemystowej. Cztowiek, red. H. Imbs, Wrocław-Warszawa-Kraków 1993, s. 75-103.

Więcławek D., Jak zabić czas i zaimponować towarzystwu? Gry i zabawy w świetle poradników XIX i XX wieku, [w:] Sport i czas wolny w perspektywie interdyscyplinarnej, red. D. Nowalska-Kapuścik, G. Libor, 2018, s. 47-53.

Zieliński K., Żydzi Lubelszczyzny 1914-1918, Lublin 1999.

Żarnowska A., Codziennośći kultura. Wkregu rodziny i wśród innych, [w:] Kobieta ikulturażycia codziennego, t. 5: Wiek XIX i XX, red. A. Żarnowska, A. Szwarc, Warszawa 1997, s. 17-28.

\section{Netografia}

Turnau L., Wspomnienia $z$ pobytu w Lublinie, http://biblioteka.teatrnn.pl/dlibra/Content/10829/Wspomnienie_z_pobytu_w_Lublinie.pdf (dostęp: 20 X 2020). 
Anna Jakimowicz

\section{IN THE SHADOW OF WAR... CULTURE AND FREE TIME OF THE MILITARY AND CIVILIAN POPULATION IN LUBLIN DURING THE AUSTRO-HUNGARIAN OCCUPATION (1915-1918)}

Summary. In the fall of 1915, Lublin became the capital of the General Military Governorate, which resulted in an influx of military and civilians from C.K. Monarchy and Galicia. Free time from work was filled with visits to theaters, cinemas, as well as restaurants and confectioneries, which resulted in the flourishing of the cultural sphere, and also the catering, hotel and service industries. Local entrepreneurs, wanting to gain the favor of the occupation authorities, tried to meet their needs and expectations, which was not easy in the face of requisitioning goods, high prices and speculation, and difficult communication. Nevertheless, during the entire period of the occupation, new forms and places of entertainment appeared, the purpose of which was to entertain and temporarily forget from everyday worries. They were used by both officers and civilians, but at that time also two posts were created for military personnel.

Keywords: Lublin, culture, entertainment, free time, Great War, Austro-Hungarian occupation 